УДК $37.011+37.013 .74$

DOI:

Тетяна Завгородня, доктор педагогічних наук, професор, завідувач кафедри педагогіки та освітнього менеджменту імені Богдана Ступарика ДВНЗ “Прикарпатський національний університет імені Василя Стефаника”

Інна Стражнікова, доктор педагогічних наук, доцент, професор

кафедри педагогіки та освітнього менеджменту імені Богдана Ступарика ДВНЗ “Прикарпатський начіональний університет імені Василя Стефаника”

\title{
УКРАЇНСЬКІ ПЕДАГОГИ ПРО ПРОБЛЕМИ ВИХОВАННЯ І НАВЧАННЯ В КИТАЇ
}

У статті показані результати аналізу досліджень українських науковців навчально-виховних проблем різних вікових категорій та їх вирішення в Китайській Народній Республіиі, з точки зору компаративістики. Адже компаративістика орієнтована на розкриття закономірностей діючої освітньої системи у різних краӥнах, спільного й відмінного у їх розвитку. Автори представили аналіз останніх публікаџій та розкриття проблеми на науково-практичних конференціях різного рівня. А враховуючи, що КНР $\epsilon$ однією з країн з найінтенсивнішими темпами та найбільш вражаючими результатами суспільно-політичного та сочіальноекономічного розвитку, особливостями побудови й функиіонування сучасноӥ системи освіти КНР, то сучасна система освіти китайських дітей спрямована на всебічний розвиток дитини, розкриття його розумового $і$ фізичного потенціалу та інтегрованості у суспільство, зокрема дітей-сиріт.

Ключові слова: компаративістика; виховання; навчання; піклування; Китайська Народна Республіка; Україна; трансформація.

Jim. 8.

Tetyana Zavhorodnya, Doctor of Sciences (Pedagogy), Professor, Head of the Bohdan Stuparyk Pedagogy and Educational Management Department, State Pedagogical University "Vasyl Stefanyk Precarpathian National University"

Inna Strazhnikova, Doctor of Sciences (Pedagogy), Associate Professor,

Professor of the Bohdan Stuparyk Pedagogy and Educational Management Department, State Pedagogical University "Vasyl Stefanyk Precarpathian National University”

\section{UKRAINIAN EDUCATORS ON THE PROBLEMS OF EDUCATION AND TRAINING IN CHINA}

The results of analysis of studies of Ukrainian scientists of educational problems of different age categories and their solutions in the People's Republic of China from a comparative perspective are presented in the article. Comparative science is aimed at revealing the laws of the current educational system in different countries, common and different in their development. The authors presented an analysis of recent publications and the disclosure of the problem in the works of scientific conferences of various levels. And considering that PRC is one of the countries with the most intense rates and the most impressive results of socio-political and socio-economic development, features of the construction and functioning of the modern system of education of PRS, the modern system of education of Chinese children is aimed at the comprehensive development of the child, the disclosure of his mental and physical capacity.

Exploring the influence of traditions on education, Chinese scienists note that the traditional component is manifested in the educational process, on the whole because of its content and is associated with the basic value attitudes and stereotypes of behavior characteristic of the ideal personality, model that was created by national Chinese ideologues in its time. The directions of Chinese education are based on traditional values and at the same time determine its current state, saturated with the ideas of humanism and oriented to the demands of the globalized world.

The Chinese experience of organizing the system of working with orphan children in different countries is examined, especially in the present-day PRC, which aims at integrating orphans into society on equal opportunities, eliminating the consequences of orphanage and preventing this phenomenon from occurring or minimizing it.

Therefore, the search for general/excellent, specific/positive/negative in the educational systems of different countries, acquaintance with the international experience of education reforming provide an opportunity to comprehend and find a scientific interpretation of the educational traditions and enrich the Ukrainian national education system.

Keywords: comparative studies; an education; teaching; care; the People's Republic of China; Ukraine; transformation.

П остановка проблеми. Трансформація суспільного устрою в Україні, прагнення інтегруватись в європейський

культурний та економічний простір вимагають кардинальних змін в суспільному житті, в тому числі і в освіті та вихованні молоді. Враховуючи, 
що такі процеси (успішні, або невдалі) відбуваються у багатьох країнах світу і нерідко мають дотики з процесами в Україні, важливо постійно вивчати, аналізувати зміни, що відбуваються в різних країнах, наявність існуючих проблем, виникнення ускладнень у їх вирішенні, а також врахування можливих шляхів їх успішного розв'язання. Саме необхідністю розв'язання проблем, які висуваються змінами, і відбуваються сьогодні в суспільстві різних країн пояснюється той факт, що в останні роки частіше проводяться наукові конференції різного рівня: “Педагогічні теорія і практика в контексті інтеграційних процесів" (Тернопіль, 2014), IV Всеукраїнський педагогічний конгрес "Реформування освітньої системи в Україні в контексті Європейської інтеграції” (Львів, 2014), “VI українсько-польські історико-педагогічні читання “Розвиток української і Польської освіти і педагогічної думки (XIX - XXI ст.)" (Львів, 2015); 3'являються наукові дослідження з проблем розвитку освіти в різних країнах світу: "Педагогічна освіта Австрії XIX - початку XX ст.” (М.С. М'ясковський), “Модернізація дошкільної освіти у Польщі” (1989 - 2017 рр.) (Б. Мажец), “Якість освіти в Польщі (друга половина XX - початок XXI століття" (М. Кічула); “Забезпечення якості загальної освіти в Німеччині засобами вдосконалення оцінювання роботи школи” (Н. Шеверун); “Традиції та інновації в процесі інтенсифікації управління освітою в Німеччині” (А. Джурило), “Характеристика практичної підготовки у медичних університетах Австрії й України” (Г. Кліщ) та ін. Також значна увага науковців присвячена розкриттю проблем загальної середньої освіти різних країн: Франції (С. Сгоров); Фінляндії(Л. Волинець); функціонування початкової освіти: Англія, Уельс, Північна Ірландія, Шотландія (Борисенко І.); системі забезпечення якості вищої освіти в країнах Західної Свропи (О. Цюк, Ю. Заячук); управління навчальними закладами туристського профілю Швейцарії (Н. Закордонець) та ін. Особливо грунтовним 3 проблем порівняльної педагогіки є дослідження на тему “Компаративізм як світоглядна складова формування мислення майбутніх учителів початкової школи в процесі історико-педагогічної підготовки” (В. Вихрущ, Л. Решетуха).

Аналіз останніх досліджень і публікацій. Досвід вирішення проблем усіх галузей педагогіки як системи наук в конкретній країні світу, або через порівняння підходів до їх розв'язання науковцями різних країн, рекомендації щодо творчого використання виявленого педагогічного досвіду зарубіжних країн чи регіонів цікаво представлено у наукових розвідках: “Приватне шкільництво у Вільнюсі в 1918 - 1939 роках” (С. Валесик, Польща); “Автодидактизм як спроба переосмислення сутності організації навчального процесу в приватній початковій освіті (XIX - початок XX століття)" (В. Вихрущ, Л. Романишин); "Українське шкільництво воєнних біженців в Австрії та Чехії під час Першої світової війни" (К. Рендзінський, Польща) та ін. Неважко помітити, що практично в кожному науковому повідомленні присутні елементи порівняльної педагогіки.

Кожна з розвідок розкриває й сучасні проблеми освіти і виховання, які виникли в різних країнах світу, шляхи їх розв'язання або досвід конкретної країни, або у порівнянні з іншими країнами.

Аналіз педагогічних досліджень останніх десятиліть засвідчує, що їх теоретичну основу поряд із концепціями сучасної філософії освіти (В. Андрущенко, І. Бех, В. Бондар, І.Зязюн, В. Кремінь, Н. Скотна, Г Філіпчук. та ін.), теоретичними положеннями в галузі історико-педагогічних досліджень (Л. Ваховський,А. Вихрущ, С. Гончаренко, Н.Гупан, С. Золотухіна, М. Стельмахович, Б. Ступарик, В. Сухомлинський, С. Хриков, В. Шпак та ін.), теоретико-методичних підходів до процесу виховання (С. Бочаров, М. Пантюк, В. Рогозіна, I. Стражнікова та ін.) та теоретичних основ до навчання особистості (В. Паламарчук та ін.) становлять концептуальні положення методології порівняльної педагогіки, яку як галузь педагогічної науки нерідко називають педагогікою компаративістики (О. Заболотна, В. Кемінь, В. Кравець, О. Локшина, Л. Лук'янова, Н. Ничкало, А. Сбруєва та ін.), а також методології дослідження педагогічної персоналії як пріоритету XXI століття (А. Вихрущ, О. Сухомлинська та iн.), вивчення персоналій як важливої умови зростання ефективності педагогічних досліджень загалом (Т. Завгородня, О. Сухомлинська, М. Чепіль та ін.).

Мета статті. Дослідження теоретичних основ компаративістського напряму досліджень українських науковців у контексті проблем виховання і навчання у Китаї.

Виклад основного матеріалу. Вагомим внеском у збагачення педагогічної науки і конкретно порівняльної педагогіки $є$ науковий доробок доктора педагогічних наук, професора Олени Локшиної. Саме їй належить обгрунтування трансформації педагогічної компаративістики від iii зародження (1817 р.) до сьогодення [4, 7 - 13], а також важливий висновок про формування у XXI столітті нового виміру “методології порівняльнопедагогічних студій, в якому модернізуються існуючі та народжуються нові методи світової 
компаративістики" $[4,11]$. Все це, як зазначає дослідниця, впливає на “активізацію розвитку порівняльної педагогіки під впливом глобалізаційних процесів, її збагачення новими характеристиками, примножуючи старі" $[4,11]$. На основі зроблених наукових пошуків та узагальнення їх результатів дослідниця відстоює діюче для компаративістів правило, яке називає “золотим, суть якого полягає в тому, що розгляд освітнього феномену повинен відбуватися в історико-соціально-економіко-культурному контексті” [4, 11]. Крім того компаративістинауковці зберегли ще ряд правил. Серед них обов'язковість на основі виявлення спільностей/ відмінностей виведення тенденцій/закономірностей розвитку; посилення практико-зорієнтованості порівняльно-педагогічних розвідок через “"перетив надання рекомендацій розробникам освітньої політики для удосконалення національної освіти" $[4,12]$. Але враховуючи, що у 1990-х рр. відбулись сутнісні зміни методологічних засад, 1) “процес трансформацій стартував 3 розвідок лінійного характеру на початку 90-х рр. та вийшов на рівень багатовимірності”, 2) “предмет дослідження українських науковців вже не обмежується системами освіти зарубіжних країн, а є широким спектром педагогічних феноменів - освітньої політики, релігійно-, культурно-, громадянськопедагогічних аспектів, моделей забезпечення якості освіти, освітніх реформ підготовки вчителів, ІКТ-освіти”; 3 ) “обов'язкове залучення елементу часового порівняння для підсилення формату географічного” $[4,12]$; 4) “...включення до досліджень історії питання, простежування історичних витоків проблеми" $[6,12]$. Пояснює це науковець тим, що “часове порівняння додає аналізу глибини”. А отже не важко помітити, що розглядаючи характер методологічних трансформацій української компаративістики ми констатуємо, що багато в чому вони мають дотики до методологічних засад історикопедагогічних досліджень. А це, в свою чергу, ставить науковців-компаративістів перед необхідністю при здійсненні наукових досліджень компаративістського спрямування дотримуватися і основних методологічних засад історикопедагогічних досліджень.

За твердженням О. Локшиної “за двадцять 3 невеликим років національна порівняльна педагогіки пройшла шлях, який інші школи компаративістики додали не одне десятиліття" $[4,13]$.

Вагомим внеском у розвиток порівняльної педагогіки $є$ матеріали досліджень компаративістського змісту науковців не тільки
України, але й інших країн та проведення у ЗВО, наукових установах науково-практичних конференцій різного рівня, у яких є секції обговорення проблеми компаративістики. Прикладом може служити Міжнародна науковопрактична конференція "Педагогічна теорія і практика в контексті інтеграційних процесів" (м. Тернопіль, 25 - 26 квітня 2014), організаторами якої були Вища школа економіки та інновацій (Люблін, Польща), Інститут Педагогіки НАПН України, лабораторія порівняльної педагогіки. Аналіз матеріалів конференції дає підстави стверджувати, що при обговоренні на засіданнях переважна більшість виступів була присвячена проблемам компаративістики. Так, 14 виступів презентували результати стану розв'язання окремих психолого-педагогічних проблем в окремих зарубіжних країнах, 6 виступів були присвячені стану, пошуку шляхів інтенсифікації різних педагогічних процесів в умовах формування освітнього простору, глобалізації в Україні чи інших країнах або в усій Європі. Водночас лише 4 статті присвячені порівняльному аналізу стану конкретної педагогічної проблеми деяких країн: “Карикулум початкової освіти Англії, Уельсу, Північної Ірландії та Шотландії” (І. Борисенко), “Досвід США з оцінювання досягнень учнів як джерело реформування китайської системи освіти” (О. Шпарик), “Характеристика практичної підготовки у медичних університетах Австрії й України" (Г. Кліт) й "Професійна підготовка бакалаврів комп'ютерних наук в університетах Японії та України” (І. Пододідемко). Отже, за нашими спостереженнями в останнє десятиліття спостерігається тенденція чисельного зростання досліджень 3 проблем компаративістики. Проте потребують активізації науковцями досліджень 3 порівняльного аналізу стану розв'язання існуючих проблем у різних ланках діючої системи освіти України та інших країн 3 дотриманням рекомендацій нового виміру “методології порівняльно-педагогічних студій, в якому модернізуються існуючі та народжуються нові методи світової компаративістики" $[4,11]$. Аналогічну проблему спостерігаємо і серед результатів дослідження учасників IV міжнародної наукової конференції "Порівняльна педагогіка в умовах міжнародного співробітництва та Європейської інтеграціі” (листопад 2009 року Державний університет імені О.С. Пушкіна (м. Брест, Білорусь). Опрацювання збірника матеріалів конференції, який вийшов у двох частинах, засвідчило наявність значної кількості публікацій, в яких представлено результати компаративістських досліджень. 
Проблема ролі сучасної сім’ї у вихованні молодого покоління обговорювалася учасниками на II міжнародній науково-практичній конференції “Сучасна сім'я і проблеми сімейного виховання" (Могильовський державний університет імені А.А. Кулішова (Білорусь) 20 березня 2012 р.). Учасники конференції у своїх виступах піднімали питання: “Педагогічні проблеми сімейного виховання дітей дошкільного і шкільного віку”, “Соціально-педагогічні, соціологічні, правові проблеми сімейного виховання”, "Взаємодія освіти і сім'ї в сучасних соціокультурних умовах“, "Партнерство закладів освіти і сім’ї у вихованні дітей з особливими потребами”, “Формування сімейних цінностей студентської молоді” тощо. Проте ряд виступів були присвячені розкриттю досвіду сімейного виховання в різних країнах (Білорусі, України, Молдови, Росії, Дагестану та ін.), а окремі носили компаративістське спрямування (“ЗЗарубіжний досвід підвищення педагогічної культури батьків молодших школярів в сучасних умовах", “Взаємодія педагога і сім'ї 3 виховання загальнолюдських цінностей у дошкільнят: зарубіжний досвід”). Проте слід зауважити, що при обговоренні такої важливої й актуальної сьогодні теми, яка постійно знаходиться в центрі уваги науковців різних країн, на конференції було представлено шляхи розв'язання проблеми в окремих країнах близького зарубіжжя, проте недостатньо представлено зарубіжний досвід, або порівняльний аналіз різних країн, що, безперечно, знизило не тільки психолого-педагогічну цінність отриманої інформації, а й ії соціальне значення.

Така ситуація потребує розв'язання низки проблем з урахуванням світового досвіду. Тому, в останні роки в багатьох країнах світу актуальними є наукові розвідки порівняльного характеру. Зокрема, предметом окремих досліджень різних психолого-педагогічних проблем українських науковців стали питання сімейного виховання, опіки дітей і молоді в КНР. Так, особливостям різних напрямів виховання в Китаї на сучасному етапі присвячені публікації українських науковців М.Б. Свтуха та Л.С. Калашник [5], Л.В. Бережної, Н. Дічек, К. Олійникова, О.Шпарик таін.; російських-Н.Боревської,Я.Бергер, Т.Бессонової, М. Боєнко, М. Гуліної та ін.; індійських - Я. Джан; французьких - Ж. Доменак; китайських - Ду Я, Ей Ю.

Як засвідчують реалії сьогодення ці суспільні переміни несуть із собою негативні явища: безробіття, виїзди батьків за кордон, залишаючи дітей без батьківської турботи, поширення наркоманії і алкоголізму тощо. Все це послаблює сім’ю, знижує іiї виховний вплив на дітей, веде до зниження ефективності виховної роботи з ними, породжує дитячу бездоглядність з усіма їі негативними наслідками. В таких умовах зростає роль опіки над дітьми і молоддю, яка здійснюється державними й різними громадськими організаціями. Проте сьогодні $€$ ще багато питань в цій ділянці суспільного життя, які вимагають вирішення. Напевно тому у науковій літературі, педагогічних дослідженнях останніх десятиліть значна увага приділяється проблемі опіки над дітьми та молоддю, пошуку шляхів

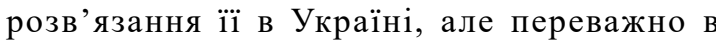
європейському і світовому контексті, де процеси трансформації суспільства мають багато подібного (Польща), або дотичні в окремих питаннях (Китай, Японія, Норвегія тощо).

На сучасному етапі виникає проблема дитячого сирітства як соціального явища. Саме складна соціально-економічна ситуація безпосередньо впливає на сім'ю, відображається на загальному контексті сімейних проблем і конфліктів, що спричиняє значну кількість негативних явищ, $з$ яких найбільш зростаючим $\epsilon$ дитяче сирітство.

Ця проблема не оминула й сучасну Україну, для якої характерним є зростання кількості дітейсиріт і дітей, позбавлених батьківського піклування; безпритульних дітей, дітей-вулиці; дітей, що перебувають у диспанцерах, установах пенітенціарної служби України, дітей, які відносяться до різних груп ризику; дітей із соціально неблагополучних сімей тощо. А економічні реалії унеможливлюють зростання усиновлення чи встановлення опікунства українськими сім'ями над такої групою дітей, що призводить до збільшення їх кількості у закладах соціального захисту (близько 80\% українських дітей-сиріт при живих батьках) [7]. У зв'язку з цим виникають установи різного типу для дітейсиріт, але численні дослідження психологів і педагогів засвідчують, що влаштування дитини до закладу інтернатного типу не забезпечує задоволення іiї основних потреб, що нерідко призводить до порушення розвитку самої дитини, неготовності її до самостійності, пошуку роботи та збереження в умовах безробіття, невмінні організувати свій побут, дозвілля, створити та зберегти власну сім'ю.

Згідно відкритих джерелінформаціїЛ. Владімірова наводить такі дані, що 310000 випускників державних установ соціального піклування для дітей-сиріт і дітей, що перебувають у скрутній життєвій ситуації, протягом року “самостійного” життя в середньому 500 осіб потрапляють на 
лаву підсудних, 3000 - стають безхатьками, 1500 - кінчають життя самогубством [2, 8]. Це відбувається внаслідок ряду факторів, що гальмують реалізацію в життя програм соціального захисту: неготовність суспільства до програм національного всиновлення у визначеному урядом обсязі; відсутність механізмів психологічної підтримки всиновлювачів і тих кого всиновлюють; механізму контролю та покарання щодо неякісного виконання обов'язків; певна кількість дітей-сиріт з вадами здоров'я та психіки, які мають мінімальні шанси бути всиновленими $[1,8]$. А тому, зазначає Л. Калашник, “на перехідному етапі увага має приділятись не тільки впровадженню нових форм соціального піклування дітей-сиріт, але також і реформуванню існуючої системи інтернатних установ" $[3,8]$.

В останні роки в Україні впроваджується відмова від інтернатних форм утримання дітей і збільшення сімейних форм виховання: влаштування дітей до прийомних сімей і будинків сімейного типу, створення корпусу професійних замісних родин як для постійного проживання дітей-сиріт і дітей, позбавлених батьківського піклування, так і тимчасового перебування $[1,8]$.

У зв'язку з цим заслуговує на увагу досвід організації системи роботи 3 дітьми-сиротами в різних країнах, особливо, як зазначає Л. Калашник, в сучасній КНР, яка спрямована на інтегрування дітей-сиріт у суспільство на правах рівних можливостей, усунення наслідків сирітства та на недопущення появи цього явища або зведення його до мінімуму $[3,8]$. Самі китайські педагоги класичної доби не приділяли уваги питанням організації роботи 3 дітьми-сиротами, тому що “...сама наявність дітей-сиріт належала не до площини педагогіки чи соціальних пошуків, а до етики..." [3, 9]. Окремі розвідки з організації побуту дітей-сиріт з боку територіальної громади та чиновників на місцях зустрічаються у працях Дацзянь Хуейнень, Конфуція, Лао Цзи, Янь Ши та ін. У цілому китайська наукова думка не підтримує положення, що діти-сироти - це окрема категорія дітей; вважається, що для недопущення прояву комплексу неповноцінності у таких дітей їх слід виховувати тими самими методами та засобами, як і решту дітей. Дане положення $є$ “подовжувачем педагогічних традицій КНР, яке було запозичено з СРСР та спирається на досвід організації виховних закладів для дітей-сиріт А. Макаренко, Ліги Порятунку дітей ім. Короленко, шкіл соціалістичного виховання, диткомун, об'єднаних дитячих будинків, що діяли в Україні у 1920 - 1930-ті рр. " [3, 10].

Аналіз дослідження показав, що науковець розглянула проблему цілісно й грунтовно. Автор виокремила соціально-історичні передумови становлення системи соціального піклування дітей-сиріт у Китаї, було зроблено порівняльний аналіз поняття "сирітство" в українській i китайській науці та практиці, виявлено їх особливості в кожній з країн. Особлива увага приділена автором обгрунтуванню сім’ї як формотворчого феномену класичного китайського суспільства і розкрито форми соціального піклування дітей-сиріт у Класичному Китаї (прийняття дитини в родину родичів; опіка дитини 3 боку громади; опіка дитини з боку держави; передача дитини на всиновлення не родичами; передача дитини до релігійних організацій, до закладів релігійного спрямування, які були засновані іноземцями, до дитячих будинків тощо).

Заслуговує на увагу інформація дослідниці про використання досвіду Івановського інтербудинку (у 1920 - 1960-х рр. перебували китайські вихованці) для формування системи соціального піклування про дітей-сиріт у сучасному Китаї. Тут було три відділення: дошкільне, молодших школярів і старших. Китайських дітей, як зазначає В. Усов, умовно можна було розділити на 3 групи: діти загиблих героїв, діти вищих партійних керівників, діти кадрових працівників партії, які приїхали на навчання в СРСР [8]. Крім того автором узагальнено теоретичні питання організації соціально-педагогічної роботи з дітьмисиротами у КНР у контексті цього напряму роботи в Україні, розкриті питання соціального партнерства в системі державного піклування [8, 63 - 76], представлена діяльність державних соціальних програм щодо зменшення рівня сирітства у сучасному Китаї ("Контроль кількості населення", “Пропаганда ненароджуваності”, "Пропаганда вільних стосунків між чоловіком і жінкою як прояв гендерної рівності”, “Пропаганда пізніх шлюбів”, “Усунення упередженості щодо дітей-сиріт у суспільстві”, “Національне всиновлення", “Наявність спеціального статусу “дитина народу”, “Організація служб з підтримки батьків-усиновлювачів”, “Підвищення авторитету родини”, “Всиновлення іноземцями” та ін.) [8, 77 - 98], водночас дається оцінка сучасному стану системи соціального піклування про дітей-сиріт у КНР (дитячий будинок і дитяче селище - основна форма державних закладів системи соціального піклування, "Велика четвірка" - основа виховного процесу у цих закладах - трудове, фізичне, моральне, ідеологічне виховання; інші напрями виховання подаються у контексті підготовки педагогічного персоналу до роботи в таких закладах). 
У сучасному Китаї питання змісту виховної роботи в різних групах населення є дуже актуальним і стоїть гостро. Лозунг “Виховання 3 метою підвищення якості нації” обговорюється на сторінках як педагогічних, так і суспільнополітичних видань. Автор схематично подав ідею “якісної нації” за китайським уявленням.

Також автор представив практичну сторону соціального піклування та організацію освіти окремих категорій у сучасному Китаї - система освіти дітей і підлітків у КНР; соціальна турбота про дітей-інвалідів у КНР; робота з обдарованими дітьми в сучасному Китаї (на прикладі шкілінтернатів для спортивно-обдарованих дітей).

Висновки. Отже, сьогодні китайське керівництво дотримується максимальної інтегрованості дітей-сиріт у життя. Тому питання соціального піклування про дітей-сиріт у КНР розглядається у єдності з загальною системою організації освітнього процесу в закладах освіти країни. Таким чином, позиція сучасних українських і китайських науковців щодо проблеми опіки дітей і молоді суголосні і визначаються як необхідність посилення опікунсько-виховної функції всіх освітніх закладів країн.

\section{ЛІТЕРАТУРА}

1. Бережна Л. Упровадження альтернативних форм опіки дітей-сиріт в Україні. Гуманітарний вісник. 2012. № 19. С. 7-11.

2. Владимирова Л. Дети и общество. Грани общества. 1999. Август. С. 8-9.

3. Калашник Л. Система соціального піклування про дітей-сиріт у КНР: монографія. Харків, 2014. 282 с.

4. Локшина О. Методологічні трансформації педагогічної компаративістики. Матеріали Міжнародної наук.-практ.конф. "Педагогічна теорія і практика в контексті інтеграційних процесів". Тернопіль, 2014. С.7-13.

5. Проблеми освіти. Науково-методичний збірник / (кол.авт.). Наук.-метод. центр вищої освіти, 2004. Вип. 38. С. 75-82.

6. Сбруєва А. Порівняльна педагогіка: навчальний посібник. Суми, 1999. 300с.

7. Украина 2013: итоги года. Независимое бюро новостей. URL: nbnews.com.ua/ru/tema/ 109312.

8. Усов В. Они жили в советском интердоме (три книги китайцев с воспоминаниями о годах проведенных в СССР. Проблемы Дальнего Востока. 2007. №3. С. 25-134.

\section{REFERENCES}

1. Berezhna, L. (2012). Uprovadzhennia alternatyvnukh formopiky ditei syritv Ukraini [Introduction of alternative forms of care for orphans in Ukraine]. Humanitarian Herald. No.19. pp.7-11.[in Ukrainian].

2. Vladimirova, L. (1999). Deti i obshchestvo [Children and society]. The margins of society.August. pp.8-9.[in Russian].

3. Kalashnyk, L. (2014). Systema sotsialnogo pikluvannia pro ditei-syrit $u K N R$ [The social care system for orphans in the PRC: a monograph]. $282 \mathrm{p}$. [in Ukrainian].

4. Lokshyna, O. (2014). Metodologichni transformacii pedagogichnoi komparatyvistyky [Methodological Transformations of Pedagogical Comparative Studies]. Materialy Mizhnarodnoi nauk.-prakt.konf. "Pedagogichna teoriia $i$ praktyka $v$ konteksti integratsiinykh protcesiv" - Proceedings of the International Scientific-Practical Conf. "Pedagogical theory and practice in the context of integration processes". Ternopil, pp.7-13. [in Ukrainian].

5. Problemy osvity (2004).[Problems of education]. Scientific and methodical collection. Scientific method. higher education center, Vol.38. pp.75-82.[in Ukrainian].

6. Sbryieva, A. (1999). Porivnyalna pedagogika: navchalnyi posibnyk [Comparative pedagogy: a tutorial]. Sumy, 300 p. [in Ukrainian].

7. Ukraina 2013: itogi goda [Ukraine 2013: the results of the year]. Independent News Office. Available at: http: nbnews.com.ua/ru/tema/109312. [in Russian].

8. Usov, V. (2007). Oni gyli v sovetskom interdome (tri knigi kitaytcev s vospominaniiami o godakh provedennykh v SSSR) [They lived in the Soviet interhouse (three books by the Chinese with memories of the years spent in the USSR]. Problems of the Far East. No.3. pp.25-134.[in Russian].

Стаття надійшла до редакції 07.10.2019

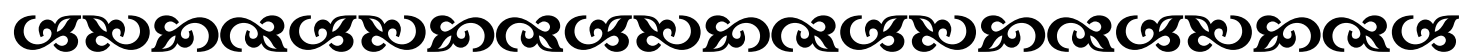

“Розумний завжди охоплює споқусою сқазати дуже багато”.

Tाеодор Адорно

німецький білособ

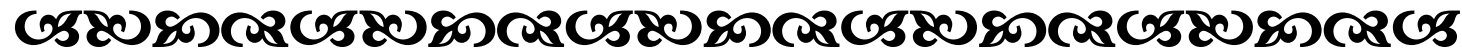

Молодь і ринок №12 (179), 2019 